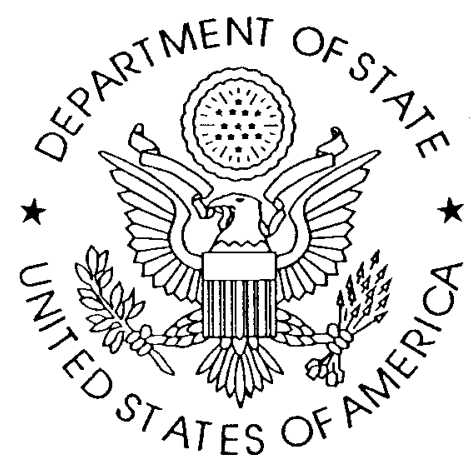

\title{
1996 Human Rights Report on Afghanistan
}

U.S. Department of State 
Afghanistan in 1996 continued to experience civil war and politicat instability, although more of the country was free of fighting and violence than in past vears. There was no central government. At year's end, the Pashtun-dominatedultra-conservative Islamic movement known as the Taliban had captured the capital of Kabul and expanded its control to over two-thirds of the country. General Abdul Rashid Dostam, an ethnic Uzbek, controlled several north-central provinces. After the loss of Kabul, former President Burhanuddin Rabbani and his military commander, Ahmed Shah Masood, controlled only three northeastern provinces. Rabbani and Dostam formed an alliance to check the growing power of the Taliban.

Taliban forces took Kabul on September 26-27 after Masood's forces retreated northward. The Taliban gained some ground north of Kabul, but were pushed back by the combined forces of Masood and Dostam. The year ended in a military stalemate. Despite intensive efforts, United Nations Special Envoy Norbert Holl did not secure a cease-fire agreement but made some progress towards getting the factions to begin political talks. The fighting forced thousands of Afghans to flee their homes in Kabul, areas north of Kabul, and in the northwestern and eastern parts of the country.

There is no constitution, rule of law, or independent judiciary. Former President Rabbani, relocated to Takhar in the north, claimed that he remained the head of the Government of Afghanistan. His delegation retained Afghanistan's U.N. seat after the U.N. General Assembly deferred a decision on Afghanistan's credentials. The Taliban, led by Mullah Mohammed Omar, formed a six-member ruling council in Kabul which ruled by edict. Ultimate authority for Taliban rule rested in the Taliban's inner Shura (Councill, located in the southern city of Kandahar, and in Mullah Omar. In Taliban.areas, order was established by disarming the local commanders and the populace and by instituting stiff punishments for crimes. Several provincial administrations maintained limited functions. Civil institutions were mostly nonexistent. General Dostam has established some administration in the 5-6 north-central provinces under his control, including customs collection at border points, but law and order in these areas is enforced by local commanders. The ethnic Tajik-majority areas of the northeast were controlled by Masood's commanders and his political organization.

* The American Embassy in Kabul has been closed for security reasons since January, 1989. Information on the human rights situation is therefore limited. 
Agriculture, including high levels of opium poppy cultivation, remained the mainstay of the economy. Afghanistan has become the second largest opium producer in the world. Lack of resources and the war have impeded reconstruction of irrigation systems, repair of market roads, and replanting of orchards in some areas. The presence of an estimated 10 million land mines has restricted areas for cultivation and slowed the return of refugees who are needed to rebuild the economy. The laying of new mine fields, primarily by pro-Rabbani forces but also by General Dostam's forces, exacerbated an already difficult situation. Trade was mainly in fruits, minerals, and gems, as well as goods smuggled to Pakistan. Formal economic activity remained minimal and was inhibited by recurrent fighting and roads blocked by local commanders. These blockages were removed in territory taken by the Taliban. Reconstruction was continuing in Herat, Kandahar, and Jalalabad, although efforts in the latter city were slowed by renewed hostilities in the fall. Reconstruction in some northern areas, including Balkh province, reportedly continues.

Serious human rights violations continued to occur and citizens were precluded from changing their government peacefully. Political killings, torture, rape, arbitrary detention, looting, abductions and kidnapings for ransom were committed by armed units, local commanders, and rogue individuals. Prison conditions were poor. Various factions infringed on citizens' privacy rights. Summary justice was common. The Taliban instituted Is/amic courts and enforced their interpretation of appropriate Islamic punishments, such as public executions and amputations of one hand and one foot for theft. For minor infractions, Taliban militiamen often decided right or wrong and meted out punishments such as beatings on the spot. Both Taliban and anti-Taliban forces were responsible for the indiscriminate bombardment of civilian areas, particularly Kabul. Taliban forces rocketed and shelled Kabul when it was held by Rabbani, killing hundreds of civilians. After Kabul fell, Dostam and Masood's forces also bombed the city, but caused many fewer casualties. Civil war conditions and the unfettered actions of competing factions effectively limited the freedoms of speech, press, assembly, association, religion, and movement. There was widespread discrimination against women and girls, and the condition of women and girls in Kabul and Herat after the Taliban captured these cities was significantly worse than in 1995. The Taliban prohibited women from working outside the home except in the health care field. Girls were prohibited from attending school. However, the imposition of Taliban control in rural areas resulted in reduced incidents of rape, kidnaping, and forced marriage. Workerrights were not defined. 


\section{RESPECT FOR HUMAN RIGHTS}

Section 1 Respect for the Integrity of the Person, Including Freedom from:

a. Political and Other Extrajudicial Killing

A number of personal and politically-motivated killings reportedly took place during the chaos when the Taliban took Jalalabad in mid-September. For example, a group of commanders and members of the Nangarhar Council were ambushed and killed near the border town of Torkham. The attack was presumed to be retaliation for a Council-sanctioned killing of the assailant's brother several years earlier. When the Taliban captured Kabul in late September, one of their first acts was to invade the U.N. compound, seize former President Najibullah and his brother, and summarily execute them. Najibullah was head of the secret police during the Soviet occupation and President of Afghanistan from 1986-92. The corpses were hung in the street for 2 days following the executions. According to Amnesty International, at least 30 men were taken from Herat prison in July and executed by Taliban authorities. In October there were unconfirmed reports that 20 civilians were executed by Taliban forces north of Kabul as the Taliban forces withdrew under pressure from Masood's forces. There were also reports of atrocities against civilians by Dostam's forces.

Commander Rasul Pahlawan, a prominent northern leader, was killed in June, reportedly by one of his bodyguards who then was killed by the other bodyguards. Dostam, who many thought ordered the killing, denied involvement and established a commission of inquiry into the slaying. The assassin's family reportedly had had land and political disputes with Pahlawan. Since Pahlawan's slaying, intra-factional fighting within Dostam's political organization reportedly has resulted in some deaths.

In other areas, combatants sought to kill rival commanders and their sympathizers. The perpetrators of these killings and their motives were difficult to identify, as political motives are often entwined with family and tribal feuds, battles over the drug trade, and personal vendettas. In March fighting broke out in Baghlan near the town of Pul-i-Khumri after Ismaili forces reportedly ambushed and killed a Hezb-i-Islami commander loyal to Gulbuddin Hekmatyar and some of his men.

The Taliban used swift s.ummary trials and implemented strict punishments according to Islamic law; the Taliban ordered public executions and death by stoning (see Sections 1.c. and 1.e.)

\section{b. Disappearance}

Abductions, kidnapings, or hostage-taking for ransom or political reasons occurred in non-Taliban areas, but specific information was lacking. An unconfirmed report claimed that in July, political associates of Ahmed Shah Masood kidnaped six individuals in Takhar who were accused of being political opponents of Masood and held them for ransom. The strict security enforced by the Taliban in areas under their control has resulted in a decrease in such crimes.

There were unconfirmed reports of girls and young women being kidnaped by local 
commanders in the southeast, Jalalabad, Kabul, and other areas before these areas came under Taliban control. Some of the women were then forced to marry their kidnapers. Others simply remained missing. To avoid this situation, some families sent their daughters to Pakistan. There were also reports that women had been killed by their male relatives to prevent forced marriages (see Section 5).

Groups in Russia listed nearly 300 former Soviet soldiers who had served in Afghanistan as missing in action or prisoners of war. Most were thought to be dead or to have voluntarily assimilated into Afghan society. Some allegedly continued to be held against their will by their Afghan captors. A number of persons from Ukraine, Belarus, and Kazakstan remain missing from the period of the Soviet occupation and are presumed dead. Their remains have not been found.

\section{c. Torture and Other Cruel, Inhuman, or Degrading Treatment or Punishment}

Afghanistan is in a state of civil war and torture is used against opponents and prisoners of war (POW's), though specific information is generally lacking. Torture does not appear to be a routine practice in most areas. Some of Masood's commanders in the north reportedly used torture routinely to extract information from and break the will of prisoners and political opponents; some of the victims were said to have been tortured to death. Local authorities maintain prisons in territories under their control and established torture cells in some of them. The Taliban freed many prisoners as they took control of new areas, but also incarcerated new prisoners. The Taliban operate prisons in Kandahar, Herat, Kabul, and Jalalabad. There are also prisons in the north in Mazar-i-Sharif and Faizabad, Badakhshan province. According to Amnesty International (Al), some Taliban prisoners have been forced to labor in life-threatening conditions such as digging trenches in mined areas, though these reports are unconfirmed.

The Taliban ruled strictly in areas they controlled, establishing ad hoc and rudimentary judicial systems. Taliban courts imposed their interpretation of Islamic laws and punishments following swift summary trials. Murderers were subjected to public executions (see Section 1.a.) and thieves had a limb or two (one hand, one foot) severed. Adulterers were stoned to death. In July a couple was convicted of adultery by a Taliban court.. The couple was reportedly stoned to death in a public place in Kandahar. In August a man was hanged from a crane for murder and left dangling for 20 minutes. The body was reportedly taken to the hospital before burial. However, the hospital staff discovered that the man was still alive. The Taliban reportedly pardoned the man who is now venerated.

Prison conditions are poor. Prisoners are given no food. Normally, this is the responsibility of prisoners' relatives who are allowed to visit to provide them with food once or twice a week. Those who have no relatives have to petition the local council or rely on other inmates. Prisoners live in collective cells. The U.N. Special Rapporteur for Human Rights in Afghanistan visited prisoners in Mazar-I-Sharif and Kandahar in July. Local authorities allowed the ICRC to visit detainees throughout the country. 


\section{d. Arbitrary Arrest, Detention, or Exile}

With the absence of formal legal and law enforcement institutions, justice was not administered according to formal legal codes. Judicial and police procedures varied from locality to locality. Little is known about the procedures for taking persons into custody and bringing them to justice. In both Taliban and non-Taliban areas, the practices varied depending on the locality, the local commanders, and other authorities. Some areas have more of a judicial structure than others. A seven-member Russian air crew, detained by the Taliban in Kandahar since August 1995, managed to escape in August. While performing maintenance on their downed aircraft at the airport, the crewmen overpowered their guards and took off in their plane to freedom.

Between January and June, the International Committee of the Red Cross (ICRC) visited over 2,000 detainees in 38 places of detention. Following the Taliban's capture of Kabul in September, the ICRC confirmed that all the detainees it had previously visited in the capital had been released. There were unconfirmed reports that the Taliban had freed prisoners in the southeast and the east as they captured these areas in August and September. In early October, the ICRC began visits to detainees newly-arrested by the Taliban in Kabul and Jalalabad.

In October Al claimed that the Taliban had detained up to 1,000 civilians during house to house searches in the initial days after the fall of Kabul. The families feared that the prisoners were sent to clear mine fields for the Taliban in the Panjshir valley. This report was not confirmed. Al reported other cases of individuals detained by the Taliban because of their ethnic origin, suspected sympathy with Taliban opponents, or opposition to Taliban religious decrees.

Political detainees are probably held by all factions but no firm numbers are available. Perhaps as many as 1,000 soldiers are held by opposing groups as POW's. In November the ICRC reported that 600 former Rabbani/Masood soldiers were held by the Taliban. Masood reportedly holds several hundred Taliban soldiers as POWs.

The authorities are not known to use forced exile.

\section{e. Denial of Fair Public Trial}

With no functioning nationwide judicial system, many municipal and provincial authorities relied on some form of Shari'a (Islamic) law and traditional tribal codes of justice.

Little is known about the administration of justice in the areas controlled by Dostam and Rabbani/Masood in the northern provinces. The administration and implementation of justice could vary from area to area and depend on the whims of local commanders or pther authorities, who could summarily execute, torture, and mete out punishments without reference to any other authority. In Rabbani/Masood-controlled Badakhshan province, one commander used a scaffold outside his headquarters to hang several individuals convicted of serious crimes by 
local Islamic courts. In March three alleged criminals were hanged in public in Kabul, then under Rabbani's control.

The Taliban established Islamic courts in areas under their control to judge criminal cases and resolve disputes. These courts meted out punishments to dozens of prisoners, including execution and amputation. These courts are said to have heard cases in sessions that lasted only a few minutes. Reportedly one such court in Kandahar usually consisted of four judges who gathered in a room or courtyard. Both the witnesses and the accused were brought before the judges to recount testimony and plead their cases. Prisoners were often brought forward in shackles. The court reportedly dealt with all complaints, relying on Islamic law and punishments as well as traditional tribal customs (see Section 1.c.). In cases involving murder, convicted prisoners were generally ordered executed by relatives of the victim (see Section 1.a.), who could choose to accept other restitution. Decisions of the courts were reportedly final.

In January, according to press reports, a man was executed in Logar province for murdering a neighbor during a dispute. Local Taliban authorities arrested and tried the man, who was executed by a firing squad led by the victim's brother after the victim's family refused to forgive the man or accept money as compensation. Also in January, a man in Herat, also controlled by the Taliban, was executed by hanging at a local sports arena, reportedly for murder.

In February according to press reports, a Taliban court in Khost tried and convicted two men of murder in separate crimes. After rejecting any offer of money as compensation, the victims' male relatives carried out the sentence with a Kalashnikov rifle. The convicted men were blindfolded with hands and feet tied, placed one at a time in front of a large tree in a public area, and executed.

In July the Taliban allegedly executed without trial 30 to 50 pro-Rabbani troops or supporters captured by the Taliban in Herat and Ghor provinces. In the western province of Nimruz, three men were publicly hanged in August by the Taliban after having been found guilty of planting landmines. In November, according to press reports, two men were executed in Kandahar by order of an Islamic court for sexually assaulting and murdering a boy and a girl. In December, a man convicted of killing a woman and children.by Rabbani's courts in Kabul and who escaped from prison in the confusion following the Taliban takeover, was recaptured by the Taliban. A Taliban Islamic court affirmed the earlier conviction and allowed the husband of the murdered woman to forgive the murderer or kill the murderer himself. He chose the latter and shot the murderer to death in Kabul stadium.

Shi'a Islamic legal norms are reportedly imposed in the Hazarajat in central Afghanistan. According to the October report of the U.N. Special Rapporteur for Human Rights in Afghanistan (see Section 4), the Shi'a Unity Party (Hezb-i-Wahdat) in Bamian province has established a Judicial Committee. The Committee has a prosecutor's office çomposed of three branches for political, military, and social offenders. There were also courts of the first and the final instance. 
All factions probably hold political prisoners but no firm estimates of numbers are available.

f. Arbitrary Interference with Privacy, Family, Home, or Correspondence

Intrafactional fighting often resulted in the homes and businesses of civilians being invaded and looted by the opposing forces--whether victor or loser. Armed gunmen acted with impunity given the absence of any legal protection from the law or a responsive police force. In Kabul and Jalalabad prior to the Taliban takeover, armed individuals reportedly forced their way into homes without fear of reprisal. It was unclear what authority controlled the actions of Taliban militiamen who patrolled the streets of cities and towns, and several incidents were reported of Taliban soldiers entering private homes without prior notification or informed consent in Kabul, Herat, Kandahar, and elsewhere. In Kabul the soldiers allegedly searched homes for evidence of cooperation with the former authorities. Individuals were beaten on the streets by the Taliban for what were deemed infractions of Taliban rules. However, following a written order in December by Mullah Omar to Taliban followers warning against beating citizens, the practice diminished.

According to the U.N. High Commissioner for Refugees (UNHCR), approximately 300 single men were registered in October who claimed to be fleeing forced conscription by the Taliban. There were unconfirmed reports that after the takeover of Kabul, the Taliban rounded up young men to be soldiers and Panshiri Tajiks were seized in Kabul and taken to undisclosed locations.

The Taliban and Dostam's political organizations infringed on women's freedom of expression by requiring strict Islamic garb in public (see Section 5).

g. Use of Excessive Force and Violations of Humanitarian Law in Internal Conflicts

The Taliban killed approximately 325 civilians in Kabul in 1996 by indiscriminately firing rockets into the city. Approximately 675 civilians in Kabul were injured during the year because of the civil war. The Taliban reportedly conducted aerial bombing raids in October around Kalakan, approximately 12 miles north of Kabul, and caused the deaths of 16 to 20 civilians, including women and children. According to press reports, in October Taliban units destroyed 120 houses in the Tajik-dominated village of Sar Cheshma, five miles north of Kabul. From October to December, Dostam's and Masood's forces engaged in sporadic bombing and rocket attacks against Kabul. Several persons, including children, were killed and injured in separate attacks.

At the beginning of the year, the UNHCR reported that there were approximately 150,000 internally displaced persons (IDP's) in camps near Jalalabad and as many as 200,000 living independently in and around Jalalabad city. Between 25,000 and 27,000 IDP's were reported to be living in camps in the north in Pul-i-Khumri, Mazar-i-Sharif, Shibergan, and Hairatan. In November thousands of persons fled fighting in the northwest province of Badghiz. Twelve hundred of these IDP's passed 
through UNHCR camps in the Herat area, and 700 remained in camps as of late December Some 6,000 to 7,000 had headed north into Turkmenistan, but many of those had returned. The UNHCR said that 15,000 Afghans, mostly from Kabul, had crossed into Pakistan since October and that 600 to 700 were arriving daily. From October to December, UNHCR estimated that about 40,000 Afghans fled to Pakistan due to the intensified civil war.

The Afghan countryside remains plagued by an estimated 10 million land mines sown during and since the Soviet occupation. With funding from international donors, the United Nations has organized and trained mine detection and clearance teams, which operated throughout Afghanistan. Nevertheless, the mines are expected to pose a threat for years to come. The laying of new mine fields by Masood forces around Kabul and Sarobi, a strategic city southeast of Kabul, posed new dangers. U.N. agencies and other nongovernmental organizations (NGO's) have instituted a number of mine awareness campaigns and educational programs for women and children in various parts of the country, but many were curtailed as a result of Taliban restrictions on women and girls.

Section 2 Respect for Civil Liberties, Including:

\section{a. Freedom of S.peech and Press}

There are no laws effectively providing for freedom of speech and the press, and the Kabul authorities under Rabbani for the first 9 months of the year lacked the authority to protect these rights. Senior officials of various warring factions allegedly attempted to intimidate reporters and influence their reporting. The Afghan Islamic Press (AIP) is an unaffiliated reporting service. The few newspapers, all of which were published only sporadically, were largely affiliated with different factions. There was a pro-Rabbani radio and television service in Kabul until it came under Taliban control and was renamed the Voice of Shariat. The various regions had their own radio and television stations: Dostam had his own in the northern city of Mazar-I-Sharif and Hekmatyar had his own near Kabul until they were taken over by the Taliban. Herat's media came under Taliban control when they captured the city in September 1995.

International journalists in Kabul reported that they were routinely pressured by the Rabbani regime to slant their coverage. The Taliban by and large cooperated with the international press who arrived in Kabul in September and took few steps to curb their access. However, a female Western journalist was not allowed to attend the Taliban's first press conference in Kabul. In another incident, one commander discouraged Taliban officials from responding to questions posed by Western female journalists. One female correspondent reported that she and her camera crew were jostled by Taliban soldiers while filming in Kabul. There were several incidents in which photographers' film was seized after taking pictures of women. In October two Argentine journalists were reportedly detained for 24 hours and beaten by Taliban militia after they attempted to interview two Afghan women in Kabul. At times Western journalists were prevented from traveling to the front lines, although many succeeded in doing so on other occasions.

Despite some incidents most journalists, including women, were able to do their jobs. 
In November the Taliban imposed a rule requring journalists to stay at the Intercontinental Hotel in Kabul (allegedly for security and economic reasons). Journalists also reported at year's end that the Taliban were attempting to controf who could act as drivers and interpreters for journalists.

The Taliban imposed its interpretation of Islam on popular culture, banning music, movies, and television. Cinemas in Kabul had already been closed by authorities in June before the Taliban takeover.

The Taliban severely restricts academic freedom, particularly education for girls (see Section 5).

\section{b. Freedom of Peaceful Assembly and Association}

Civil war, tenuous security, and likely opposition from local authorities seriously inhibited freedom of assembly and association. Nonetheless, Afghans demonstrated in several cities. There were credible reports of women demonstrating in Herat against Taliban strictures, of persons encouraged by the Taliban to demonstrate in Kabul and Kandahar against Iranian interference, and of demonstrations in Mazar-i-Sharif against the Taliban. In one demonstration in Herat, Taliban adherents reportedly beat the female demonstrators.

There were reports of Taliban harassment of international aid agencies and NGOs. In the fall, the Taliban detained Afghan staffers of UNHCR, broke into the office and home of one international staffer, and confiscated vehicles. Other NGO staffers, mostly Afghan, were also detained. Some female Afghan staffers were threatened with punishment if they went to work.

It is unknown whether laws exist governing the formation of associations. The Taliban reportedly issued an edict at year's end which outlawed all social organizations, but this was unconfirmed. Many Afghan NGOs have been formed. Some are based in neighboring countries, mostly Pakistan, with branches inside Afghanistan. Others are based in Afghan cities. The focus of their activities is primarily humanitarian assistance, rehabilitation, health, education, and agriculture.

\section{c. Freedom of Religion}

Afghanistan's official name, the Islamic State of Afghanistan, reflects the country's adherence to Islam as the state religion. Some 85 percent of the population is Sunni Muslim, with Shi'a Muslims comprising most of the remainder. The Hazara ethnic group is Shi'a; Shi'as are among the most economically disadvantaged people in Afghanistan. The Shi'a minority want a national government to give them equal rights as citizens. There were unconfirmed reports that under Taliban rule, the Shi'a populations in Kabul and Herat were forced to pray in the open-handed Sunni style, rather than in their own, closed-handed style. Miniature stones, representing the sacred black stone at the Kaaba in Mecca, were removed from Shi'a mosques. Shi'as were forced to pray at the same time as Sunnis, although traditionally their prayer schedules differ. However, at year's end it appeared the Taliban were not interfering 
in Shi'a prayer practices.

The Taliban sought to impose their strict form of Islamic observance in areas that they control. Men were hauled out of their vehicles and forced to attend services at mosques. Taliban members attempted to force men to pray five times a day at set times and to grow long beards. Ismaili women were not allowed to leave home to attend Ismaili religious services and Ismaili girls were not allowed to attend school. The Taliban also ordered women to dress in strict Islamic garb (see Section 5).

The small number of non-Muslim residents in Afghanistan may practice their faith, but may not proselytize. The country's small Hindu and Sikh population, which once numbered about 50,000, continued to shrink as its members emigrated or took refuge abroad. Some Taliban leaders claimed tolerance of religious minorities. There were unconfirmed reports that a number of Sikhs, who have long felt unwelcome by the various mujaheddin commanders, had returned to Jalalabad, Ghazni, and Kabul under the Taliban to reclaim their property and resume residence.

d. Freedom of Movement Within the Country, Foreign Travel, Emigration, and Repatriation

Although in principle citizens have the right to travel freely both inside and outside the country, their ability to travel within the country was hampered by warfare, brigandage, millions of land mines, a road network in a state of disrepair, and limited domestic air service, complicated by factional threats to air traffic. Despite these obstacles many people continued to travel relatively freely with buses plying routes in most parts of the country. Security conditions have improved along roads in Taliban-controlled areas. However, due to intermittent fighting in various areas, international aid agencies often found that their ability to travel, work, and distribute assistance was hampered. International travel continued to be difficult as both Dostam and the Taliban threatened to shoot down any planes that overflew areas of the country that they controlled without their permission. In December, the Taliban forced down a U.N. plane carrying a Tajik opposition leader from Iran to Afghanistan. The Taliban said the U.N. had not informed them of the flight. After a diversion to Kandahar, the plane was allowed to proceed.

Commercial trade was impeded in certain non-Taliban areas as local commanders continued to demonstrate their control over the roads by demanding road tolls and sometimes closing roads. In January one road stoppage at Sarobi on the Kabul-Jalalabad road by a Hekmatyar commander prevented trucks carrying food supplies from reaching Kabul for about a week. Roads leading to Bamian province reportedly contained dozens of checkpoints controlled by local commanders, where travelers were sometimes subject to extortion.

According to the UNHCR, approximately 10,000 people reportedly fled Jalalabad following the Taliban takeover in mid-September, but most later returned. Villagers were forced to flee the fighting north and northeast of Kabul in several locations as factions contended for control village by village. A large number of Kabul inhabitants were also displaced by the Taliban takeover in late September, but there were no reliable estimates as to their number. In November fighting in Badghis province in the 
northwest caused thousands to flee their homes. More than 9,000 displaced persons were concentrated in 3 areas of northern Afghanistan by mid-November. The UNHCR said that 15,000 Afghans, mostly from Kabul, had crossed the border to Pakistan since the beginning of October. While, according to UNHCR statistics, the overall* number of families returning to Kabul was greater than the number departing in 1996 , the number of departing families rose sharply in September and continued at a high level throughout the remainder of the year. The rate of arrival in Pakistan in October was 600 to 700 a day. By year's end, the UNHCR and NGO's were assisting more than 1,600 newly arrived families (11,200 persons) in Nasir Bagh camp in Pakistan. Since October the Taliban have reportedly removed dozens of checkpoints on the Kabul-Jalalabad road; at year's end there were only six. They routinely checked passengers for weapons and "stolen state property."

Afghans continued to form one of the world's largest refugee populations. According to the UNHCR, about 2.4 million Afghans remain outside the country in 1996 as registered refugees. Of these, 1.3 million are in Iran, 864,000 are in Pakistan, and 28,000 are in Russia. Approximately 19,000 Afghans reside in parts of the former Soviet Union other than Russia. Pakistan claimed an additional 500,000 unregistered Afghan refugees in its territory. Over 3.8 million Afghan refugees have been repatriated since 1988 , with over 1.5 million returning to Afghanistan in the peak year of 1992. According to the UNHCR, 127,500 Afghans repatriated in 1996, 120,000 from Pakistan and 7,500 from Iran. The repatriation from Iran was much lower than in previous years. This reflected in part the Iranian Government's decision not to encourage repatriation while the Taliban remained in control of western Afghanistan and to postpone use of a new repatriation route through Turkmenistan.

It also reflected the judgment of many refugees that their prospects for earning a livelihood were better in Iran than in Afghanistan.

According to the UNHCR, approximately 18,800 refugees from Tajikistan remain in Afghanistan. About 1,000 Tajik refugees were repatriated to Tajikistan during 1996. Tajiks living in the UNHCR-run Saki camp near Mazar-i-Sharif have been able to repatriate relatively freely. Those in camps in the Kunduz area, which is controlled by Masood, Hekmatyar, and independent commanders and where the Tajik opposition actively opposes repatriation, have not had free access to information on repatriation. The UNHCR does not have access to these camps. The refugees have also faced considerable difficulty in repatriating when they have wished to do so. However, according to the UNHCR, the opposition's hold on the camps has decreased in recent months, and some repatriation has occurred.

Section 3 Respect for Political Rights: The Right of Citizens to Change Their Government

The continuing struggle for political power among the three major armed groups precluded citizens from changing their government or form of government peacefully and democratically. Mpst political changes came about through shifting military fortunes. No faction held elections or respected the right to change government democratically. 
The faction controlling Kabul for the first 9 months of the year, headed by nominal President Rabbani, held power with the military backing of de facto Defense Minister Masood, until the Taliban takeover in late September. General Dostam was aligned with Hezb-I-Islami (Islamic Party) leader Gulbuddin Hekmatyar and with an opposition Shi'a party in an alliance called the Supreme Coordination Council of Afghanistan. The Taliban controlled all of southern and western Afghanistan to the Turkmenistan and Iranian borders. In June former Rabbani rival Gulbuddin Hekmatyar switched sides and joined the Rabbani government as Prime Minister. The move was intended to broaden the base of the Kabul regime to include Pashtuns. However, the step weakened the allegiance of Hekmatyar's commanders in the southeast and east and led to the crumbling of the formerly neutral Nangarhar Shura (Council) in the east. After the fall of Jalalabad, Sarobi, and then Kabul, Rabbani fled to Takhar in the north where he proclaimed that the Government had relocated. At year's end, Rabbani and Masood controlled two Tajik majority northeastern provinces, Badakhshan and Takhar, as well as pockets in Kunduz, Parwan, and Kapisa, including the Panjshir valley. Hekmatyar continued to command allegiance from several commanders located in Baghlan and Kunduz provinces. Dostam's National Islamic Movement controlled five to six north central provinces. After the fall of Kabul, Rabbani/Masood, Dostam, and the Khalili-led Shi'a Party formed an alliance, the Supreme Council for the Defense of Afghanistan, to combat the Taliban.

Although there are governors and local councils in the north, most power there is concentrated in the hands of Dostam and a few generals. Masood retains control in the northeastern ethnic Tajik-majority provinces through his commanders and political organization. The three eastern provinces--Nangarhar, Laghman, and Konar--were controlled by a neutral commander, but all fell to the Taliban in mid-September. The Taliban controlled more than two-thirds of the country by year's end, including Kabul. However, discontent with Taliban strictures and village values was strong in large non-Pashtun cities such as Herat and Kabul.

In September former King Zahir Shah declared from his residence in exile that he was prepared to return to Afghanistan and discuss with the relevant parties the formation of an interim government. Although many representatives of the factions visited the former King, he did not return to the country. The Taliban were ambivalent about a possible role for the former King, although some Taliban adherents supported his return. Some observers believed that some Afghans welcomed the Taliban to their areas because they thought that they were the former King's vanguard.

The United Nations and the international community continued their efforts to help Afghans reach a political settlement. In April and October, the U.N. Security Council held open discussions on Afghanistan. In October a Security Council resolution was adopted that called for an end to the fighting and the start of a political dialogue aimed at national reconciliation and a lasting political settlement. It also called upon the outside parties to stop supplying arms and ammunition to the warring factions and for all Afghan groups to respect human rights and permit the delivery of humanitarian assistance.

In the fall, attempts by U.N. Special Envoy Holl to broker a ceasefire among the parties failed. However, Holl succeeded in getting talks underway between two of the 
major groups, Dostam and the Taliban. In October the Organization of Islamic States (OIC) called for a peace conference of Afghans in Jeddah, but received no positive response. On November 18, the U.N. Secretary General convened a meeting $\rho f$ countries concerned with the Afghan situation to bolster international support for the U.N.'s mediation efforts and to engage the neighboring and regional states in a common approach to the conflict.

Section 4 Governmental Attitude Regarding International and Nongovernmental Investigation of Alleged Violations of Human Rights

There was no functioning central government in the country. The Rabbani regime cooperated with the U.N. Special Rapporteur for Human Rights in Afghanistan, Dr. Choong-hyun Paik, who traveled to Afghanistan in January and May 1995, visiting Kabul, Herat, Kandahar, Jalalabad, and Mazar-i-Sharif. In February his report to the U.N. Commission on Human Rights concluded that the lack of a central government posed extreme difficulties and complexities in redressing human rights violations. He concluded that it was necessary then to stress the importance of accountability at the level of regional administrations, which might assume responsibility for violations of human rights committed in their particular region. He noted that the collapse of an impartial judicial system prevented the administration of justice, which posed an insurmountable challenge to citizens' right to a fair trial and affected, in particular, detainees in prisons.

In April Dr. Paik's mandate as special rapporteur was renewed by the U.N. Commission on Human Rights. In July he traveled again to Afghanistan, as well as Pakistan and Iran. Also in July, the Kabul authorities under Rabbani permitted a 2-day visit to Kabul by three representatives of Amnesty International. They met with Rabbani and Dostam to discuss the human rights situation in the country. Al's requests to meet with Taliban representatives were denied.

In October the U.N. Special Rapporteur noted in his interim report that Afghanistan over the years had signed a number of international human rights conventions. However, the Taliban recognize only the validity of Islamic law. They do not accept the notion of secular law, nor binding international human rights norms. In early October, Jose Ayala Lasso, the U.N. High Commissioner for Human Rights, publicly invited the Taliban leadership to ensure respect for women's rights, such as the right of women to work and the right of girls to an education without discrimination.

The Afghan League of Human Rights operated both in Afghanistan and Pakistan; it produces an annual report. The Cooperation Center for Afghanistan (CCA) is an Afghan NGO that operated in both Pakistan and Afghanistan. CCA maintains an office in Peshawar where it produces a monthly newsletter on the Afghan human rights situation. 'It alșo works inside Afghanistan to document human rights abuses. However, the civil war and lack of security made it difficult for human rights organizations to adequately monitor the situation inside the country. In October a 
2-day workshop on human rights in Afghanistan was held in Peshawar, Pakistan.

Section 5 Discrimination Based on Race, Sex, Religion, Disability, Language, or Social Status

There are no constitutional provisions that prohibit discrimination based on race, sex, religion, disability, language, or social status. It is not known whether specific laws prohibit discrimination; local custom and practices generally prevail. Discrimination against women varies from area to area, depending on the local leadership's attitude towards work and education for women. Traditionally, the minority Shi'a faced discrimination from the majority Sunni population. There was more general acceptance of the disabled as the number of people maimed by land mines increased and the presence of the disabled became more prevalent.

\section{Women}

As lawlessness and interfactional fighting continued in some areas, violence against women occurred frequently, including beatings, rapes, forced marriages, disappearances, kidnapings, and killings. Such incidents generally went unreported and most information was anecdotal. It was difficult to document rapes, in particular, given the social stigma that surrounded the problem.

Afghan tradition imposes limits on women's activities beyond the home, particularly in the Taliban-dominated Pashtun areas of the south. Under the Communist regime of the 1980's, a growing number of women, particularly in urban areas, worked - outside the home in nontraditional roles. This trend was reversed when the Communists were ousted in 1992 and an Islamic government was installed. In 1996 the trend towards excluding women from public service continued, although some women retained employment as artisans, weavers, doctors, and nurses in some areas. In northern Afghanistan and pre-Taliban controlled Kabul, women were allowed to work and girls to attend school.

When the Taliban took Kabul in late September, they immediately issued pronouncements forbidding women to work, including female doctors and nurses in hospitals. This move affected as many as 40,000 women, including civil servants, teachers, bakers, and charwomen. Some working women appealed to the Taliban that they had no other means of livelihood to support several family members if they did not work. Taliban gender restrictions often interfered with the ability of UN relief agencies and NGO's to employ women and deliver assistance to women and girls. Many relief organizations had to scale back their activities, and at least one, Oxfam, suspended operations altogether in Taliban areas. However, most continued their principal programs. After gender restrictions threatened to disrupt the delivery of health services, the Taliban allowed some female medical staff, including doctors and nurses, to resume their jobs in Kabul and elsewhere, but generally only under strict guidelines. Female nurses were discouraged from working alongside male doctors. Male doctors could not attend to female patients. Actual practice, however, varied from place to place. The Taliban allowed female doctors and nurses

to tend other females and even, in some instances, to attend to male patients. In one 
province, a male doctor who ran a clinic was allowed to see female patients but only with his wife present.

Female employment outside of the health sector was forbidden by the Taliban in Kabul, Herat, and elsewhere. The Taliban have completely stopped women from teaching in boys' schools, thereby preventing many boys from getting an education. In Kabul and elsewhere, women were prohibited from working outside the home. The Taliban promised to pay women salaries to remain at home but did not. In Herat resistance to the Taliban's edicts forbidding employment led to punishment, including beatings. The Taliban also limited women's access to education by stopping most women's educational programs in areas they took over, including the closure of a nursing school in Kandahar.

The Taliban decreed what women would wear in public. They were required to don an all-encompassing head-to-toe garb known as the chadori which has only a mesh screen for vision. In conservative areas, this was the normal garb for rural women. In Kabul women found in public not wearing the chadori were beaten by Taliban militiamen. In one incident, a woman covered by a chadori was reportedly harassed by a Taliban street patrol in Kabul for not properly covering her bare feet. A few reports indicated that some women in Herat are covering their heads with large scarves that leave the face uncovered and have not faced reprisals.

The appearance and movement of women in public has been discouraged, even with approved clothing. In the days after the Taliban takeover of Kabul, a Taliban patrol stopped two women and beat them with a broken-off car antenna, even though they were appropriately dressed. However, women were not prevented from leaving their homes altogether. They went to the market without accompanying male relatives in Kandahar, the most socially conservative of the larger cities, as well as in Herat and Kabul, though in smaller numbers than before the Taliban takeover. Women also visited open bazaars, but were sometimes discouraged from entering small shops. Instead, they had to conduct business with the shopkeepers from the street.

Most women in Dostam-controlled Mazir-i-Sharif now wear the chador, a marked change from last year. Dostam's political organization issued strict instructions that women on the streets should be modestly attired.

In October the U.N. Secretary General issued a statement criticizing the Taliban's directive on women and warned that international assistance to Afghanistan could be jeopardized if international human rights standards were not observed. The U.N. Security Council held an open discussion on October 16 at which many countries addressed the problem of human rights in Afghanistan, particularly the rights of women and girls.

\section{Children}

Local administrative bodies and international assistance organizations undertook further children's welfare to the extent possible. Taliban restrictions on the movement of women and girls in areas that they controlled hampered the ability of U.N. agencies and NGO's to effectively implement education programs aimed at both boys and girls. 
UNICEF discontinued programs in Herat, Kandahar, and Kabul where girls were denied access to education. One NGO decided not to proceed with a planned program aimed at girls' education in Herat. The general disruption of health services countrywide due to the Soviet invasion and civil war put many young people at grave risk. UNiCEF continued to operate some health-related programs in Taliban-controlled areas. Local authorities in all parts of Afghanistan have supported UNICEF/WHO mass vaccination campaigns. Education, also disrupted due to the Soviet invasion, 10 years of resistance, and civil war caused a generation of children to miss all of their schooling, reportedly raising illiteracy levels above 75 percent.

The Taliban have stopped most of the few opportunities for girls' education that were in place in areas they have taken over. Since capturing Kandahar in 1994, there has been no girls' education--either secular or religious--in the city. Since capturing Herat city in 1995, girls' schools have remained closed. Kabul had more girls' schools than any other city. According to a U.N. survey conducted in May, Kabul had 158 public schools accommodating 148,223 boys and 103,256 girls in grades K-12. Of 11,208 teachers, 7,793 were women. According to UNICEF, no women were teaching in and no girls were attending public schools in Kabul at year's end as a result of Taliban policies on female employment and education. The effect on boys' education was unknown; 3,415 male teachers presumably were still employed. UNICEF believed that girls may still be attending a few private schools, but no details were available. However, Taliban authorities reportedly permitted girls' education in some of the rural areas of Herat province. Limited girls' education continued in Taliban-controlled Ghazni, Khost, and Konar provinces in the south, at schools and in private homes. Even in areas where education is possible, facilities are inadequate and access is limited by custom and poverty. Simple education for boys, both secular and religious, continued in Taliban-controlled areas, including Kabul. However, these opportunities were diminished since female teachers were prohibited from teaching in boys' schools.

People with Disabilities

Both the former Rabbani regime and the new Taliban authorities in Kabul took few measures to protect the rights of the mentally and physically disabled or to mandate accessibility for them. Victims of land mines, were a major focus of international humanitarian relief organizations, which devoted resources to providing prostheses, medical treatment, and rehabilitation therapy to amputees. In Jalalabad an NGO provided bicycles to amputees for transportation as well as physical therapy, rehabilitation skills, and literacy training. There was more public acceptance of people with disabilities because of the prevalence of the maimed due to land mines. The U.N. Development Program (UNDP) conducted a million dollar project to strengthen comprehensive community-based rehabilitation services for disabled citizens. The ICRC and some NGO's were actively involved in programs for people with disabilities throughout the country.

Section 6 Worker Rights

a. The Right of Association

Little is known about labor laws and practices, although only an insignificant fraction 
of the work force has ever labored in an industrial setting. There were no reports of labor rallies or strikes. Labor rights are not defined, in the context of the breakdown of governmental authority, and there is no effective central authority to enforce them. Many of Kabul's industrial workers are unemployed due to the destruction or abandonment of the city's minuscule manufacturing base. The only large employer in Kabul is the governmental structure of minimally functioning ministries.

b. The Right to Organize and Bargain Collectively

Afghanistan lacks a tradition of genuine labor-management bargaining. There are no known labor courts or other mechanisms for resolving labor disputes.

\section{c. Prohibition of Forced or Compulsory Labor}

No information is available on edicts regarding forced or compulsory labor. There were no confirmed reports of alleged forced-work road projects.

\section{d. Minimum Age for Employment of Children}

There is no evidence that authorities in any part of the country enforce labor laws, if they exist, relating to the employment of children. Children from the ages of 6 to 14 often work to help support their families by herding animals in rural areas, and by collecting paper and firewood, shining shoes, begging, or collecting scrap metal among street debris in the cities. Some of these practices expose children to the danger of land mines.

\section{e. Acceptable Conditions of Work}

There is no available information regarding a statutory minimum wage or the enforcement of safe labor practices. Many workers are apparently allotted time off regularly for prayers and observance of religious holidays. 